\title{
Effect of Learning Motivation and Learning Environment Against Student Learning Achievement
}

Vina Aulia $\mathrm{Al} \mathrm{Haq}^{1}$

1PG PAUD FKIP Universitas Muhammadiyah Surakarta

\section{ABSTRACT}

Research on the Influence Motivation Study and Environmental Learning Against Achievement Learning Students showed that There is the influence of positive motivation to learn and environmental learn to achievement learn student . case is shown by the analysis of regression linear multiple, that the value of $t$ count motivation to learn at 2.476 with significance $0.016<0.05$ then $\mathrm{HO}$ is accepted, and environmental learning has value $t$ arithmetic amounted to 4.977 with significance $0.000<0.05$ then $\mathrm{HO}$ is accepted. While the value of $\mathrm{F}$ arithmetic amounted to 53.069 , and the value of $\mathrm{R}$ square of $0.639(63.9 \%)$. Relative contribution to the variable of learning motivation give a donation of $31 \%$ and variable environment study provides donations relatively amounted to $69 \%$, the total contribution relative of $100 \%$. Donations effective at variable motivation to learn by $19.81 \%$ and environment study by $63.91 \%$, which means that the motivation to learn and environment study are jointly provide donations effectively amounted to $63.91 \%$ against the achievement of learning, and $36.09 \%$ of other variables not examined .

\section{KEY WORDS}

learning motivation, learning environment, student learning achievement

\section{CORRESPONDING AUTHOR:}

email: vinaauliaalhaq1@gmail.com

Manuscript submitted May 21, 2020; accepted June 17, 2020.

Copyright: (02020 This is an open access article under the terms of the Creative Commons Attribution License, which permits unrestricted use, distribution, and reproduction in any medium, provided the original author and source are credited.
ECRJ (Early Chilhood Research Journal)

ISSN Numbers: Print, 2655-6448; Online, 2655-9315

\section{ADDRESS}

Website: http://journals.ums.ac.id/index.php/ecrj

Address: Pendidikan Guru PAUD

Universitas Muhammadiyah Surakarta

A. Yani Street No. 1, Pabelan, Kartasura, Surakarta, Indonesia Telp. +62-271-717417 ext.

Email: ecrj@ums.ac.id

\section{INTRODUCTION}

Education is the capital to prepare a good and quality generation. According to the law on National Education System No. 20 Year 2003, education is the business conscious and planned to realize an atmosphere of learning and the process of learning so that participants learners are actively developing the potential for him to have the strength of spiritual religion , control of self, personality, intelligence, morals noble, as well as the skills that it needs itself, society, nation and state. The educational process certainly has a goal to be achieved. So that educational goals can be achieved, efforts are needed to improve the quality of education. Every education that succeeds in achieving its goals certainly has a good learning process. In the process of education is certainly has a level of education that is sustainable, from the education of children aged early to study at the university high . On the Regulation of Education of the 
Republic of Indonesia Number 17 Year 2010 on the Management and Operation of Education Article 1 point 6 namely education formal is education that is structured and tiered which consists on educational base, educational secondary and education high . Where college high is the education continuation of education schools secondary, education at college high is prepared to become a community that can think in academic and professional in doing one thing, and can spread expand science knowledge that is gained. In college high there is a college of high country and college high private. According to Law No. 12 Year 2012 College High Private whose abbreviated PTS is a college high that was set up and held by the public. One of the PTS that exist in Surakarta the University of Muhammadiyah Surakarta, Philosophy of the University of Muhammadiyah Surakarta itself, as part of a charity effort Persyarikatan Muhammadiyah, UMS is also determined to make the discourse of science and Islam as the philosophy of the organization and the development of institutions of education high. Besides that, UMS has 12 faculties one of them is the Faculty of Teacher Training and Science Education or called FKIP that inside there are 11 programs of study, one of which is a program of study Teacher Education Child Education Age Early or PG ECD. Program Study PG ECD is designed to print the educator that professionals in the field of education for children ages early . Besides that, an educator of children aged early is a teacher first that will be known by the child once at home. At the time of children aged early or at the time of the age of 0-6 years old children will do something based on what that had he seen, then from that prospective educators of children ages early sued not only express kindness but also can do a kindness . When making mistakes as an educator must be able to justify it so that children do not follow, and can know which is right, because at this early age children will be very risky for children to follow or imitate what they have seen. In the process of becoming a candidate educators of children ages early certainly have a lot of interest that would be achieved among the results of learning and achievement of learning are good and which to your desired. Achievement is a proof of the success of someone who achieved (Wingkel , 2013: 75), a person can be said to be successful in his studies if he gain the result of optimal and satisfactory in education were taken. Achievement learn student the level keberasilan in the eyes of subjects were tangible in the value of the cumulative. One of the problems that exist in the world of education especially is the low learning achievement and lack of motivation to learn . It it can be seen from the program remedial or improvement of value for students who have a value less than that already determined. Motivation by McDonald ( Sardiman , 2005: 7374) motivation is a change of energy within yourself someone who is characterized by the emergence of feeling and preceded by the response to the purpose. From here students who have the motivation that is higher then the process of learning or the desire to learn will appear, so it will create activities to learn the good and achieved objectives are desirable . With their motivation to learn the good, the side of another environmental study also affect 
the effectiveness of the learning and achievement of learning someone . Environmental study of them are people who are there in about an individual or at the point of living individuals, such as family, the parents or be friends boarding, environment are good, safe , comfortable will make people quiet, so it will encourage someone to learn , with the process of learning that someone also will get satisfaction in accomplishment. In the study of this, the authors take the environment to learn home and boarding students of PG ECD FKIP UMS, because houses and boarding is where most close to the students, from the neighborhood homes and boarding will reflect how the process of learning someone where to find the environment that is conducive it will support also the process study someone.

\section{Understanding Learning Achievement}

Hamalik (2012: 152) said that achievement is the result of intelligence or skills achieved by each individual to be able to obtain a new behavior change as a whole as a result of each individual's experience. According to (Djamarah, 2011: 12) learning is a word that is familiar to all levels of society. According to Hintzman in his book The Psychology of Learning and Memory believes Learning is a change in organism due to experience which cn the effect of organism's behavior. That is, learning is a change that occurs in an organism (human or animal) caused by experience that can affect the behavior of the organism. So, at the conclusion Hintzman explained, the change brought about by new experiences can be said to be learning if it affects organisms.

\section{Definition of Motivation}

Motivation starts from the word "motive" which can be interpreted as "the driving force that has become active". Motives become active at certain times, especially when the need to achieve goals is felt or urgent. Sadirman (Kompri, 2005: 73). Motivation is a driving force that converts energy in a person into real activities to achieve a certain goal. (Djamarah, 2011: 148)

According to (Santrock, 2014: 165) motivation is a process that gives energy, directs, engages and maintains behavior. Motivated behavior is behavior that is full of energy, directed and enduring. If there is no driving force, there is no motivational driver, if someone has high motivation it will be easy to get what they want, and vice versa if someone has no motivation or motivation, it will be difficult to achieve the goals they want to achieve.

\section{Understanding the Learning Environment}

According to Hamalik (2003: 195) environment is everything that exists in the natural surroundings that has a certain meaning or influence on individuals. According to Dalyono (2005: 132) the environment includes all the conditions in the world that exist in certain ways affecting our behavior, growth, development or our life processes except for genes and even genes can also be seen as preparing the environment for another gene .

Baharuddin (2007: 68) states that the environment is something that surrounds an individual in his life, both in the physical environment such as parents, homes, playmates and the surrounding community or 
in the form of psychological environments such as feelings experienced, ideals and problems faced. According to (Shah, 2017: 90) quantitatively, learning means the activity of filling or developing cognitive abilities with as many facts as possible.

According to Darsono (2000: 65) The learning environment is elements that come from outside the self. As is the case, healthy environmental conditions, harmony of life, social order, a safe, peaceful and beautiful environment. According to Muhibbin (2005: 135-136) the environment is divided into two, social environment and non-social environment .

\section{RESEARCH METHOD}

The approach this research is quantitative . This type of research is a descriptive study . This research was conducted in the Study Program PG-PAUD FKIP UMS . The population that is used by the researchers was a student of PG-ECD FKIP UMS as many as 164 students . Consists of 4th semester forces in 2017 with the number of 57 students, then the 6th semester forces in 2016 with the number of 57 students and 8 semesters force in 2015 with the number of 50 students. The population in this study is quite large, so researchers used samples in the study. In the calculation using the Taro Yamene formula obtained a sample of 62 from a population of 164 students. Mechanical taking samples of the research is to use propotionate stratified random sampling . Data collection techniques using questionnaires and documentation. Mechanical Analysis of data using Analysis
Statistics Descriptive, Test Prerequisites Analysis Data and Analysis Multi Regression .

\section{RESULTS AND DISCUSSION}

Based on data analysis using multiple regression tests, based on the results of learning motivation variables have $=2.476$ with significance $=0.016<0.05$, it is accepted which means that there is a real influence ( significance ). Then it can be concluded that learning motivation has a positive effect on learning achievement. Motivation is a boost in self individual to achieve a goal . Individuals who have the motivation high or powerful to be able to hit all the barriers and obstacles to reach a goal that diingikan. The more high motivation to learn the increasingly high anyway achievement learn student. Contribution relative to the variable motivation to learn to give a donation of $31 \%$ and variable environment study provides donations relatively amounted to $69 \%$, the total contribution relative of $100 \%$. Donations effectively in variable motivation to learn by $19.81 \%$ and environment study by $63.91 \%$, which means that the motivation to learn and environment study are jointly provide donations effectively amounted to $63.91 \%$ against the achievement of learning, and $36.09 \%$ of the variable other which is not researched.

\section{DISCUSSION}

The success of an education can be seen from the achievement learn student. Each student has a condition internal different, where the condition of internally the effect on 
activities of daily. Conditions internally it is the motivation to learn and environmental learning . Environmental study on the research of this discount donation relative who tend lenih lot two times as much of the vatiabel motivation to learn, respect it should be considered more. Besides that, each student is expected to have the motivation to learn are high and have the environmental study that is conducive so that activities of daily in the study is also good. It is an effect of the increase in achievement learn student . as has been explained in the results of the analysis that learning motivation and learning environment have a positive influence on learning achievement . So in improving learning achievement, of course it is also necessary to increase motivation to learn and the learning environment .

Based on the discussion and conclusions that have been described, it can be Some suggestions are given as follows.

1. For study programs, to always facilitate students in activities teaching and learning in class, so as to create a conducive learning environment and can support maximum learning achievement.

2. Need to be given more attention to the learning environment variables, because these variables make a relative contribution that tends to be greater doubled compared to motivation to learn, so it is necessary pay more attention to these variables so that differences do not occur high enough.

3. For further researchers, who will examine the topic of learning achievement students, it is better to separate university courses and programs study so that the results of learning achievement values can be more focused in accordance with the program study taken.

\section{CONCLUSION}

There is the influence of positive motivation to learn and environmental learn to achievement learn student . case is shown by the analysis of regression linear multiple, that the value of $t$ count motivation to learn at 2.476 with significance $0.016<0.05$ then $\mathrm{HO}$ is accepted, and environmental learning has value $\mathrm{t}$ arithmetic amounted to 4.977 with significance $0.000<0.05$ then $\mathrm{HO}$ is accepted . While the value of $F$ arithmetic amounted to 53.069 , and the value of $R$ square of 0.639 (63.9\%). Relative contribution to the variable of learning motivation give a donation of $31 \%$ and variable environment study provides donations relatively amounted to $69 \%$, the total contribution relative of $100 \%$. Donations effective at variable motivation to learn by $19.81 \%$ and environment study by $63.91 \%$, which means that the motivation to learn and environment study are jointly provide donations effectively amounted to $63.91 \%$ against the achievement of learning, and $36.09 \%$ of other variables not examined.

\section{REFERENCES}

Buku Panduan Akademik. Universitas Muhammadiyah Surakarta, 2015/2016.

Buku Panduan Akademik. Universitas Muhammadiyah Surakarta, 2016/2017.

Dalyono. (2005). Psikologi Pendidikan. Jakarta: Rineka Cipta. 
Dariyo, Agus. (2007). Psikologi Perkembangan Anak Tiga Tahun Pertama. Jakarta:

Refika Aditama.

Darsono. (2000). Belajar dan Pembelajaran. Semarang: IKIP Semarang Press.

Dimyati dan Mudjiono. (2009). Belajar dan Pembelajaran. Jakarta: Rineka Cipta

Djamarah, Syaiful. (2011). Psikologi Belajar. Jakarta: Rineka Cipta.

Ghozali, Imam. (2018). Aplikasi Analisis Multivariate. Edisi 9. Fakultas Ekonomi dan

Bisnis. Semarang: Universitas Diponegoro.

Hamalik, Oemar. (2000). Psikologi Belajar dan Mengajar. Bandung: Sinar Baru

Algensindo.

Hamzah B Uno. (2013). Teori Motivasi dan Pengukurannya. Jakarta: Bumi Aksara.

Hidayat, Kharisma.2014. "Motivasi Belajar Sebagai Mediasi Pengaruh Kemandirian

Belajar dan Lingkungan Keluarga Terhadap Hasil Belajar Mata Pelajaran

Produktif Siswa Kelas X AP SMK N 2 Magelang". Econimic Educational

Analysis Journal, 3, 2014.

Kopri. (2015). Motivasi Pembelajaran Prespektif Guru dan Siswa. Bandung: Remaja

Rosdakarya.

Oemar Hamalik. (2003). Proses Belajar Mengajar. Bandung: Bumi Aksara.

Prasetya \& Abdullah. 2012. "Pengaruh Kemandirian Belajar dan Lingkungan Belajar

Siswa Terhadap Prestasi Akuntansi Kelas XI IPS SMA Negri I Sewon Bantul
Tahun Ajaran 2010/2011". Jurnal Pendidikan Akuntansi Indonesia Vol. X, No.1,

2012.

Santrock, John W. (2014). Psikologi Pendidikan. Jakarta: Salemba Humaika.

Saputra, S. T., \& Pardiman (2012). Pengaruh Disiplin Belajar dan Lingkungan Teman

Sebaya Terhadap Prestasi Belajar Mahasiswa Program Studi Pendidikan

Akuntansi Angkatan 2009 Fakultas Ekonomi Universitas Negri Yogyakarta.

Jurnal Pendidikan Akuntansi Indonesia, 94.

Siagian, Sondang. (2014). Teori Motivasi dan Aplikasinya. Jakarta: Rineka Cipta.

Siregar, Syofian. (2013). Metode Penelitian Kuantitatif. Jakarta: Kencana.

Slameto. (2013). Belajar dan Faktor-faktor yang Mempengaruhinya. Jakarta: Asdi

Mahasatya.

Sugiarto, Siagian, Dergibson, Sunaryanto, Lasono Tri, dan Oetomo, Deny S. 2001.

Teknik Sampling. Jakarta: PT Gramedia Pusat Utama.

Sugiyono. (2006), Metode Penelitian Kuantitatif Kualitatif dan R\&D. Bandung:

Alfabeta

Sugiyono. (2010). Metode penelitian Pendidikan Pendekatan Kuantitatif, Kualitatif dan

R\&D. Jakarta: Alfabeta.

Suharsimi Arikunto. (2006). Prosedur Penelitian Suatu Pendekatan Praktik. Jakarta:

Rineka Cipta. 